\title{
Screening of $\alpha$-Glucosidase Inhibitory Activity from Some Plants of Apocynaceae, Clusiaceae, Euphorbiaceae, and Rubiaceae
}

\author{
Berna Elya, Katrin Basah, Abdul Mun'im, Wulan Yuliastuti, \\ Anastasia Bangun, and Eva Kurnia Septiana \\ Department of Pharmacy, Faculty of Mathematics and Sciences, University of Indonesia, Depok 16424, Indonesia \\ Correspondence should be addressed to Berna Elya, elya64@yahoo.com
}

Received 30 July 2011; Revised 8 September 2011; Accepted 9 September 2011

Academic Editor: Munekazu Iinuma

Copyright () 2012 Berna Elya et al. This is an open access article distributed under the Creative Commons Attribution License, which permits unrestricted use, distribution, and reproduction in any medium, provided the original work is properly cited.

\begin{abstract}
Diabetes mellitus (DM) is recognized as a serious global health problem that is characterized by high blood sugar levels. Type $2 \mathrm{DM}$ is more common in diabetic populations. In this type of DM, inhibition of $\alpha$-glucosidase is a useful treatment to delay the absorption of glucose after meals. As a megabiodiversity country, Indonesia still has a lot of potential unexploited forests to be developed as a medicine source, including as the $\alpha$-glucosidase inhibitor. In this study, we determine the $\alpha$-glucosidase inhibitory activity of $80 \%$ ethanol extracts of leaves and twigs of some plants from the Apocynaceae, Clusiaceae, Euphorbiaceae, and Rubiaceae. Inhibitory activity test of the $\alpha$-glucosidase was performed in vitro using spectrophotometric methods. Compared with the control acarbose ( $\mathrm{IC}_{50} 117.20 \mu \mathrm{g} / \mathrm{mL}$ ), thirty-seven samples of forty-five were shown to be more potent $\alpha$-glucosidase inhibitors with $\mathrm{IC}_{50}$ values in the range $2.33-112.02 \mu \mathrm{g} / \mathrm{mL}$.
\end{abstract}

\section{Introduction}

Diabetes mellitus (DM) is the most common endocrine disease worldwide. About 173 million people suffer from diabetes mellitus. The number of people with diabetes mellitus will more than double over the next 25 years to reach a total of 366 million by 2030 [1]. In 2000, Indonesia is ranked the fourth largest number of people with DM, after India, China, and the United States, which is about 8.4 million people. The amount is expected to rise to 21.3 million in 2030 [2].

DM consists of several types, one of which is noninsulindependent diabetes mellitus (type $2 \mathrm{DM}$ ). This type of DM is more common, reaching $90-95 \%$ of the population with DM [3]. This increasing trend in type 2 DM has become a serious medical concern worldwide that prompts every effort in exploring for new therapeutic agents to stem its progress.

In type $2 \mathrm{DM}$, inhibition of $\alpha$-glucosidase therapy is beneficial to delay absorption of glucose after a meal [4]. $\alpha$ - glucosidase plays a role in the conversion of carbohydrates into glucose. By inhibiting $\alpha$-glucosidase, glucose levels in the blood can be returned within normal limits [5].

Natural resources provide a huge and highly diversified chemical bank from which we can explore for potential therapeutic agents by bioactivity-targeted screenings [6]. As a megabiodiversity country, Indonesia still has a lot of potential unexploited forests to be developed as a source phytopharmaca or modern medicine [7]. Opportunity exploration of medicinal plants is still very wide open in line with the development of herbal industry, herbal medicine, and phytopharmaca. Therefore, researchers try to explore the potential antidiabetic agents with the mechanism of action of $\alpha$-glucosidase inhibition in several plant species from four families: Apocynaceae, Clusiaceae, Euphorbiaceae, and Rubiaceae. The four families were chosen because members of some species have been scientifically proven to have antidiabetic activity. Based on the theory of kinship through a systematic approach to plant (chemotaxonomy), plants with the same family generally have similar chemical content, 
TABLE 1: Phytochemical screening of $80 \%$ ethanol extracts from some plants of Apocynaceae, Clusiaceae, Euphorbiaceae, and Rubiaceae.

\begin{tabular}{|c|c|c|c|c|c|c|c|}
\hline \multirow{2}{*}{ Simplicia } & \multicolumn{7}{|c|}{ Chemical contents } \\
\hline & Alkaloid & Flavonoid & Terpenoid & Tannin & Glycoside & Saponin & Anthraquinone \\
\hline \multicolumn{8}{|c|}{ Apocynaceae } \\
\hline $\begin{array}{l}\text { Beaumontia multiflora Teijsm. \& } \\
\text { Binn. Folium }\end{array}$ & + & + & - & + & + & + & + \\
\hline $\begin{array}{l}\text { Beaumontia multiflora Teijsm. \& } \\
\text { Binn. Cortex }\end{array}$ & - & - & - & - & + & + & - \\
\hline Carissa carandas L. Folium & - & + & + & + & + & + & + \\
\hline Carissa carandas L. Cortex & - & - & - & + & + & + & + \\
\hline $\begin{array}{l}\text { Ochrosia citrodora Lauterb. \& K. } \\
\text { Schum. Folium }\end{array}$ & + & - & + & + & + & + & + \\
\hline Rauvolfia sumatrana Jack Folium & + & - & + & - & + & + & - \\
\hline $\begin{array}{l}\text { Strophanthus caudatus (Blume.f.) } \\
\text { Kurz Folium }\end{array}$ & - & - & + & - & + & + & + \\
\hline $\begin{array}{l}\text { Strophanthus caudatus (Blume.f.) } \\
\text { Kurz Cortex }\end{array}$ & + & - & + & + & + & + & - \\
\hline Strophanthus gratus Baill. Folium & - & - & + & - & - & + & - \\
\hline Strophanthus gratus Baill. Cortex & + & - & + & - & + & + & - \\
\hline $\begin{array}{l}\text { Tabernaemontana sphaerocarpa } \\
\text { Blume Folium }\end{array}$ & + & - & + & - & + & + & - \\
\hline $\begin{array}{l}\text { Willughbeia tenuiflora Dyer ex } \\
\text { Hook.f Folium }\end{array}$ & - & - & + & + & + & + & - \\
\hline $\begin{array}{l}\text { Willughbeia tenuiflora Dyer ex } \\
\text { Hook.f Cortex }\end{array}$ & + & - & + & + & + & + & - \\
\hline \multicolumn{8}{|c|}{ Clusiaceae } \\
\hline $\begin{array}{l}\text { Calophyllum tomentosum Wight. } \\
\text { Folium }\end{array}$ & + & + & + & + & + & + & - \\
\hline Garcinia bancana Miq. Folium & + & - & + & + & + & + & - \\
\hline $\begin{array}{l}\text { Garcinia daedalanthera Pierre. } \\
\text { Folium }\end{array}$ & - & + & + & + & + & + & + \\
\hline $\begin{array}{l}\text { Garcinia daedalanthera Pierre. } \\
\text { Cortex }\end{array}$ & - & - & + & + & + & + & + \\
\hline $\begin{array}{l}\text { Garcinia hombroniana Pierre. } \\
\text { Folium }\end{array}$ & + & - & + & + & + & + & + \\
\hline Garcinia kydia Roxb. Folium & - & + & + & + & + & + & + \\
\hline Garcinia rigida Miq. Folium & + & + & + & + & + & + & + \\
\hline \multicolumn{8}{|c|}{ Euphorbiaceae } \\
\hline $\begin{array}{l}\text { Antidesma bunius (L.) Spreng } \\
\text { Folium }\end{array}$ & - & - & + & + & + & + & + \\
\hline $\begin{array}{l}\text { Antidesma bunius (L.) Spreng } \\
\text { Cortex }\end{array}$ & + & - & + & + & + & + & - \\
\hline Antidesma celebicum Cortex & - & - & - & + & + & + & - \\
\hline Antidesma celebicum Folium & - & + & - & + & + & + & + \\
\hline $\begin{array}{l}\text { Antidesma montanum (Blume) } \\
\text { Folium }\end{array}$ & + & - & + & + & + & + & - \\
\hline $\begin{array}{l}\text { Antidesma neurocarpum Miq. } \\
\text { Folium }\end{array}$ & + & + & - & + & + & - & + \\
\hline $\begin{array}{l}\text { Blumeodendron toksbrai (Blume.) } \\
\text { Kurz. Cortex }\end{array}$ & + & - & - & - & + & + & - \\
\hline $\begin{array}{l}\text { Blumeodendron toksbrai (Blume.) } \\
\text { Kurz. Folium }\end{array}$ & + & - & + & - & + & - & - \\
\hline Croton argyratus Blume. Folium & - & - & + & - & + & - & - \\
\hline
\end{tabular}


Table 1: Continued.

\begin{tabular}{|c|c|c|c|c|c|c|c|}
\hline \multirow{2}{*}{ Simplicia } & \multicolumn{7}{|c|}{ Chemical contents } \\
\hline & Alkaloid & Flavonoid & Terpenoid & Tannin & Glycoside & Saponin & Anthraquinone \\
\hline $\begin{array}{l}\text { Cephalomappa malloticarpa J.J.Sm. } \\
\text { Cortex }\end{array}$ & - & - & + & + & + & + & + \\
\hline $\begin{array}{l}\text { Cephalomappa malloticarpa J.J.Sm. } \\
\text { Folium }\end{array}$ & - & - & + & + & + & - & + \\
\hline Galearia filiformis Blume. Folium & + & - & + & + & + & - & + \\
\hline $\begin{array}{l}\text { Sumbaviopsis albicans (Blume) } \\
\text { J.J.Sm. Cortex }\end{array}$ & - & - & + & - & + & + & - \\
\hline $\begin{array}{l}\text { Sumbaviopsis albicans (Blume) } \\
\text { J.J.Sm. Folium }\end{array}$ & - & - & + & - & + & + & - \\
\hline $\begin{array}{l}\text { Suregada glomerulata (Blume) Baill. } \\
\text { Folium }\end{array}$ & + & - & + & - & + & - & - \\
\hline & & & Rubiaceae & & & & \\
\hline $\begin{array}{l}\text { Adina trichotoma Zoll. \& Moritzi. } \\
\text { Folium }\end{array}$ & + & - & + & - & + & - & + \\
\hline $\begin{array}{l}\text { Amaracarpus pubescens Blume. } \\
\text { Folium }\end{array}$ & + & + & + & - & + & - & + \\
\hline Canthium glabrum Blume. Folium & + & + & + & + & + & - & + \\
\hline Chiococca javanica Blume. Folium & + & + & + & - & + & - & + \\
\hline Hydnophytum formicarum Folium & + & - & + & + & + & + & - \\
\hline Hydnophytum formicarum Cortex & + & + & + & - & + & - & - \\
\hline $\begin{array}{l}\text { Nauclea calycina (Batrl.ex DC.) } \\
\text { Merr. Folium }\end{array}$ & + & - & - & + & + & - & - \\
\hline $\begin{array}{l}\text { Nauclea calycina (Batrl.ex DC.) } \\
\text { Merr. Cortex }\end{array}$ & - & + & + & + & + & - & + \\
\hline $\begin{array}{l}\text { Posoqueria latifolia (Lam.) Roem. \& } \\
\text { Schult. Folium }\end{array}$ & - & - & + & + & + & - & - \\
\hline
\end{tabular}

Key: +: present; -: absent.

so it may just have the same potential for the treatment of a disease [8].

\section{Method and Material}

2.1. Plant Material. The stem bark and leaves of plants material were collected in November 2010 and identified by Center for Plant Conservation-Bogor Botanical Garden.

2.2. Extraction. Each dried powdered of wood bark, twig and leaves $(20 \mathrm{~g})$ were extracted by reflux with ethanol $80 \%$ then evaporated.

2.3. Inhibition Assay for $\alpha$-Glucosidase Activity. The inhibition of $\alpha$-glucosidase activity was determined using the modified published method [9]. One mg of $\alpha$-glucosidase (Saccharomyces cerevisiae, Sigma-Aldrich, USA) was dissolved in $100 \mathrm{~mL}$ of phosphate buffer $(\mathrm{pH}$ 6.8) containing $200 \mathrm{mg}$ of bovine serum albumin (Merck, German). The reaction mixture consisting $10 \mu \mathrm{L}$ of sample at varying concentrations ( 0.52 to $33 \mu \mathrm{g} / \mathrm{mL}$ ) was premixed with $490 \mu \mathrm{L}$ phosphate buffer pH 6.8 and $250 \mu \mathrm{L}$ of $5 \mathrm{mM}$ p-nitrophenyl $\alpha$-D-glucopyranoside (Sigma-Aldrich, Switzerland). After preincubating at $37^{\circ} \mathrm{C}$ for $5 \mathrm{~min}, 250 \mu \mathrm{L} \alpha$-glucosidase ( $0.15 \mathrm{unit} / \mathrm{mL}$ ) was added and incubated at $37^{\circ} \mathrm{C}$ for $15 \mathrm{~min}$.
The reaction was terminated by the addition of $2000 \mu \mathrm{L}$ $\mathrm{Na}_{2} \mathrm{CO}_{3} 200 \mathrm{mM}$. $\alpha$-glucosidase activity was determined spectrophotometrically at $400 \mathrm{~nm}$ on spectrophotometer UV-Vis (Shimadzu 265, Jepang) by measuring the quantity of $p$-nitrophenol released from p-NPG. Acarbose was used as positive control of $\alpha$-glucosidase inhibitor. The concentration of the extract required to inhibit $50 \%$ of $\alpha$-glucosidase activity under the assay conditions was defined as the $\mathrm{IC}_{50}$ value.

2.4. Kinetics of Inhibition against $\alpha$-Glucosidase. Inhibition modes of sample that had the best $\alpha$-glucosidase inhibiting activity in Clusiaceae, Euphorbiaceae, and Rubiaceae were measured with increasing concentration of $p$-nitrophenyl $\alpha$ $\mathrm{D}$-glucopyranoside as a substrate in the absence or presence of ethanolic extract at different concentrations. Inhibition type was determined by the Lineweaver-Burk plots analysis of the data, which were calculated from the result according to the Michaelis-Menten kinetics.

2.5. Phytochemistry Test. In this research we performed phytochemistry test which consists of alkaloid test with Mayer, Dragendorff, and Bouchardat reagents; Flavonoid test with Shinoda and Wilson Töubock reaction; tannin test with 
TABLE 2: $\mathrm{IC}_{50}$ values of rude extracts against $\alpha$-glucosidase.

\begin{tabular}{|c|c|c|}
\hline \multicolumn{2}{|c|}{ Number Sample } & \multirow{2}{*}{$\begin{array}{c}\mathrm{IC}_{50} \\
(\mu \mathrm{g} / \mathrm{mL}) \\
117.20\end{array}$} \\
\hline$(1)$ & Acarbose & \\
\hline \multicolumn{3}{|c|}{ Apocynaceae } \\
\hline (2) & Beaumontia multiflora Teijsm. \& Binn. Folium & 79.80 \\
\hline (3) & Beaumontia multiflora Teijsm. \& Binn. Cortex & 130.20 \\
\hline (4) & Carissa carandas L.Folium & 21.14 \\
\hline (5) & Carissa carandas L.Cortex & 20.44 \\
\hline (6) & Ochrosia citrodora Lauterb. \& K. Schum. Folium & 112.02 \\
\hline (7) & Rauvolfia sumatrana Jack Folium & 174.27 \\
\hline (8) & Strophanthus caudatus (Blume.f.) Kurz Folium & 706.81 \\
\hline (9) & Strophanthus caudatus (Blume.f.) Kurz Cortex & 13.93 \\
\hline$(10)$ & Strophanthus gratus Baill.Folium & 50.61 \\
\hline (11) & Strophanthus gratus Baill. Cortex & 202.17 \\
\hline (12) & Tabernaemontana sphaerocarpa Blume Folium & 554.32 \\
\hline (13) & Willughbeia tenuiflora Dyer ex Hook.f Folium & 8.16 \\
\hline$(14)$ & Willughbeia tenuiflora Dyer ex Hook.f Cortex & 42.11 \\
\hline \multicolumn{3}{|c|}{ Clusiaceae } \\
\hline$(15)$ & Calophyllum tomentosum Wight. Folium & 15.83 \\
\hline$(16)$ & Garcinia bancana Miq. Folium & 22.41 \\
\hline (17) & Garcinia daedalanthera Pierre. Folium & 2.33 \\
\hline (18) & Garcinia daedalanthera Pierre. Cortex & 3.71 \\
\hline (19) & Garcinia hombroniana Pierre. Folium & 11.30 \\
\hline$(20)$ & Garcinia kydia Roxb. Folium & 3.88 \\
\hline$(21)$ & Garcinia rigida Miq. Folium & 24.48 \\
\hline
\end{tabular}

Euphorbiaceae

(22) Antidesma bunius (L.) Spreng Folium 7.94

(23) Antidesma bunius (L.) Spreng Cortex 3.90

(24) Antidesma celebicum Cortex 3.93

(25) Antidesma celebicum Folium 2.34

(26) Antidesma montanum (Blume) Folium 2.83

(27) Antidesma neurocarpum Miq. Folium 4.22

(28) Blumeodendron toksbrai (Blume.) Kurz. Cortex 22.82

(29) Blumeodendron toksbrai (Blume.) Kurz. Folium 64.78

(30) Croton argyratus Blume. Folium 366.07

(31) Cephalomappa malloticarpa J.J.Sm. Cortex $\quad 12.22$

(32) Cephalomappa malloticarpa J.J.Sm. Folium 2.66

(33) Galearia filiformis Blume. Folium 21.54

(34) Sumbaviopsis albicans (Blume) J.J.Sm. Cortex 42.66

(35) Sumbaviopsis albicans (Blume) J.J.Sm. Folium 43.40

(36) Suregada glomerulata (Blume) Baill. Folium 57.46

Rubiaceae

(37) Adina trichotoma Zoll. \& Moritzi. Folium

28.22

(38) Amaracarpus pubescens Blume. Folium 3.64

(39) Canthium glabrum Blume. Folium $\quad 117.85$

(40) Chiococca javanica Blume. Folium 23.86

(41) Hydnophytum formicarum Folium $\quad 181.90$

(42) Hydnophytum formicarum Cortex 11.04
TABle 2: Continued.

\begin{tabular}{llc}
\hline \multicolumn{2}{l}{ Number Sample } & $\begin{array}{c}\mathrm{IC}_{50} \\
(\mu \mathrm{g} / \mathrm{mL})\end{array}$ \\
\hline$(43)$ & Nauclea calycina (Batrl.ex DC.) Merr. Folium & 18.81 \\
$(44)$ & Nauclea calycina (Batrl.ex DC.) Merr. Cortex & 25.99 \\
$(45)$ & $\begin{array}{l}\text { Posoqueria latifolia (Lam.) Roem. \& Schult. } \\
\end{array}$ & Folium \\
\hline
\end{tabular}

gelatin test, gelatin-salt test, and test with ferrous (III) chloride; glycoside test with Molisch reaction; saponin test with honeycomb froth test; anthraquinone test with Bornträger reaction; terpenoid test with Liebermann-Burchard reagent.

\section{Results and Discussion}

3.1. Phytochemistry Test. Compounds with $\alpha$-glucosidase inhibitory activity were preliminary identificated by the existence of alkaloid, terpene, saponin, tannin, glycoside, flavonoid, and quinone (Table 1).

3.2. Assay for $\alpha$-Glucosidase Inhibitory Activity. The $\alpha$ glucosidase of $S$. cerevisiae is used to investigate the inhibitory activity of the rude extracts. $\alpha$-glucosidase inhibitory activity of rude extracts compounds against $\alpha$-glucosidases were determined using $p$-nitrophenyl- $\alpha$-D-glucopyranoside ( $\mathrm{p}$ NPG) as a substrate and these were compared with acarbose (Table 2). The $\mathrm{IC}_{50}$ values of compounds range from $2.33 \mu \mathrm{g} / \mathrm{mL}$ to $706.81 \mu \mathrm{g} / \mathrm{mL}$. There are thirty-seven of samples which have $\mathrm{IC}_{50}$ lower than acarbose. Extracts derived from leaves of Garcinia daedalanthera showed inhibitory activity against $\alpha$-glucosidase enzyme significantly, with $\mathrm{IC}_{50}$ value of $2.33 \mu \mathrm{g} / \mathrm{mL}$. Inhibitory activity of the enzyme $\alpha$ glucosidase at forty-five extracts may be due to the glycoside content in each extract. Glycosides consist of sugars that may be structurally similar to carbohydrate which is a substrate of the enzyme $\alpha$-glucosidase [10]. IC $_{50}$ value of samples of plant extracts are lower than acarbose because their active chemical compounds have no further fractionation and may have a synergistic effect in inhibiting $\alpha$-glucosidase [11].

Inhibition mode of leaves extract of Antidesma celebicum from Euphorbiaceae was investigated. Inhibition mode of $80 \%$ ethanol extract showed competitive inhibitory mode. This mode may have been due because the structure is similar with glucose. This result is similar with inhibition mode of Nojirimycin which has a competitive inhibition against $\alpha$ glucosidase [9] (Figure 1).

Inhibition mode of leaves extract of Garcinia kydia from Clusiaceae was investigated. Inhibition mode of $80 \%$ ethanol extract showed noncompetitive inhibitory mode [12] (Figure 2).

Inhibition mode of $80 \%$ ethanol extract from Amaracarpus pubescens Blume. leaves had a combination of competitive and uncompetitive inhibition. Combination of competitive and noncompetitive may have been due to the extract having more than one compound that has $\alpha$ glucosidase inhibitory activity [13] (Figure 3). 


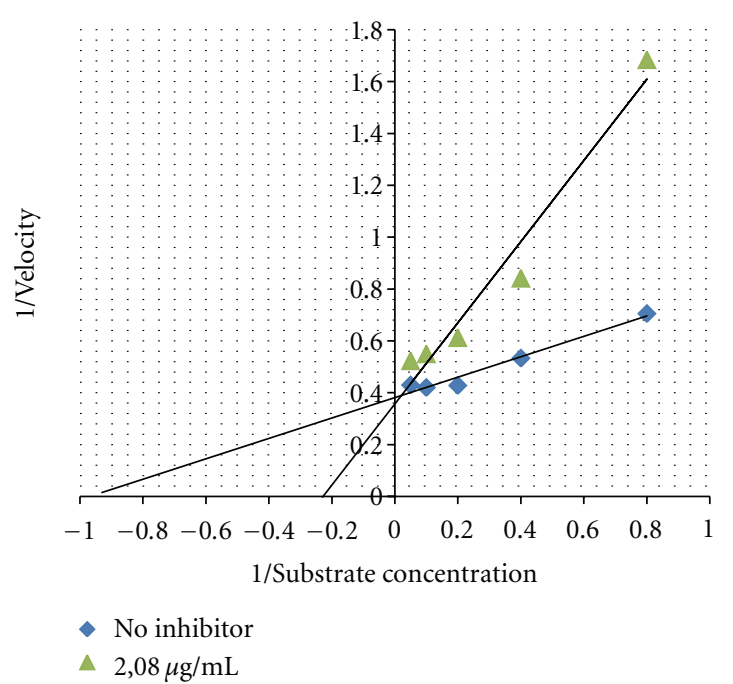

Figure 1: Lineweaver-Burk plot of $80 \%$ ethanol extract of leaves of Antidesma celebicum with concentration of $2.08 \mu \mathrm{g} / \mathrm{mL}$ with pNPG substrate concentration of $1.25,2.5,5,10$, and $20 \mathrm{mM}$.

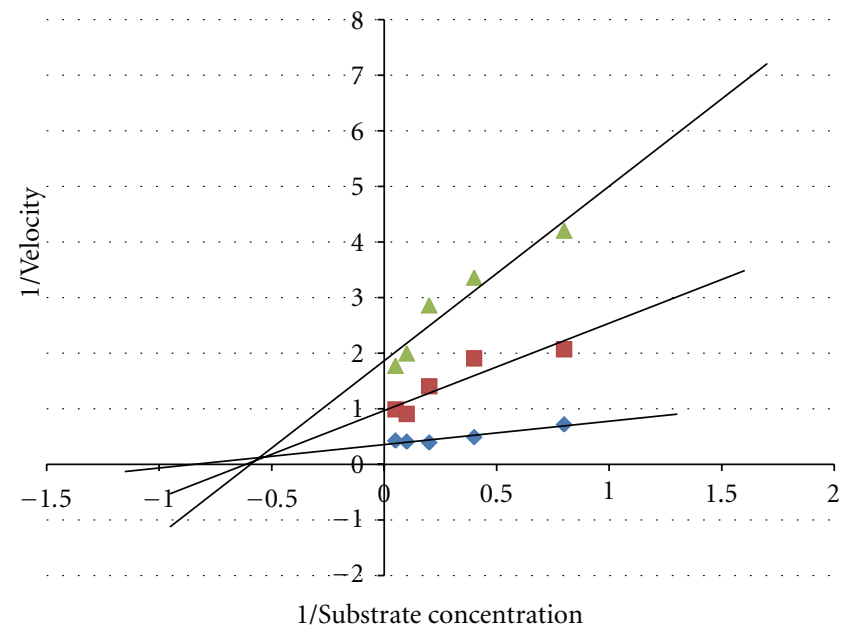

- Tanpa inhibitor

- $16,9833 \mathrm{ppm}$

\ $33.9667 \mathrm{ppm}$

FIGURE 2: Lineweaver-Burke plot of the reaction $\alpha$-glucosidase in the presence of $80 \%$ ethanol extract from Garcinia kydia Roxb. Leaves.

\section{Conclusion}

In vitro assays of $\alpha$-glucosidase activity showed thirty-seven of forty-five samples had $\mathrm{IC}_{50}$ values of between $2.33 \mu \mathrm{g} / \mathrm{mL}$ and $112.02 \mu \mathrm{g} / \mathrm{mL}$, which were lower than that of acarbose $(117.20 \mu \mathrm{g} / \mathrm{mL})$. Based on family, $80 \%$ ethanol extract from Garcinia daedalanthera Pierre. leaves (Clusiaceae), Antidesma celebicum leaves (Euphorbiaceae), Amaracarpus pubescens Blume. leaves (Rubiaceae), and Willughbeia tenuiflora Dyer ex Hook.f leaves (Apocynaceae) had the highest

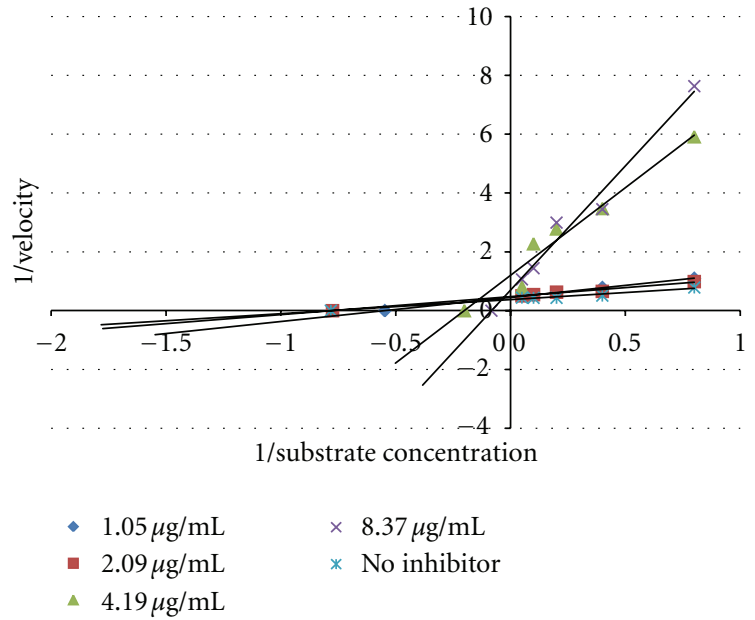

FIGURE 3: Lineweaver-Burke plot of the reaction $\alpha$-glucosidase in the presence of $80 \%$ ethanol extract from Amaracarpus pubescens Blume.

$\alpha$-glucosidase inhibiting activity with $\mathrm{IC}_{50}$ of $2.33 \mu \mathrm{g} / \mathrm{mL}$, $2.34 \mu \mathrm{g} / \mathrm{mL}, 3.64 \mu \mathrm{g} / \mathrm{mL}$, and $8,16 \mu \mathrm{g} / \mathrm{mL}$. Meanwhile, types of enzyme inhibition mechanism from Garcinia kydia Roxb. leaves (Clusiaceae), Antidesma celebicum leaves (Euphorbiaceae), and Amaracarpus pubescens Blume. leaves (Rubiaceae) were noncompetitive inhibitor, competitive inhibitor, and mixed inhibitor. Currently attempts to purify the active compound from leaves extract of Garcinia kydia Roxb. (Clusiaceae), Antidesma celebicum (Euphorbiaceae), and Amaracarpus pubescens Blume. (Rubiaceae) are conducted to understand the inhibitory mechanisms more clearly. Moreover, further in vivo study is also required.

\section{Acknowledgment}

The authors would like thank to Department of Pharmacy, Faculty of Mathematics and Natural Sciences, University of Indonesia for supporting this project.

\section{References}

[1] I. Funke and M. F. Melzig, "Traditionally used plants in diabetes therapy-phytotherapeutics as inhibitors of $\alpha$-amylase activity," Revista Brasileira de Farmacognosia Brazilian Journal of Pharmacognosy, vol. 16, no. 1, pp. 1-5, 2006.

[2] S. Wild, G. Roglic, A. Green, R. Sicree, and H. King, "Global prevalence of diabetes: estimates for the year 2000 and projections for 2030," Diabetes Care, vol. 27, no. 5, pp. 1047-1053, 2004.

[3] Department of Health Republic of Indonesia, Pharmaceutical Care for Diabetes Mellitus, Department of Health Republic of Indonesia, Kurihara, Indonesia, 2008.

[4] K. Y. Kim, K. A. Nam, H. Kurihara, and S. M. Kim, "Potent $\alpha$ glucosidase inhibitors purified from the red alga Grateloupia elliptica," Phytochemistry, vol. 69, no. 16, pp. 2820-2825, 2008.

[5] L. H. Bösenberg and D. G. Van Zyl, "The mechanism of action of oral antidiabetic drugs: a review of recent literature," Journal of Endocrinology, Metabolism and Diabetes of South Africa, vol. 13 , no. 3, pp. 80-88, 2008. 
[6] S. H. Lam, J. M. Chen, C. J. Kang, C. H. Chen, and S. S. Lee, " $\alpha$-Glucosidase inhibitors from the seeds of Syagrus romanzoffiana," Phytochemistry, vol. 69, no. 5, pp. 1173-1178, 2008.

[7] M. S. H. Wahyuningsih, S. Wahyuono, D. Santosa et al., "Plants exploration from central kalimantan forest as a source of bioactive compounds," Biodiversitas, vol. 9, pp. 169-172, 2008.

[8] L. S. De Padua, N. Bunyapiaphatsara, and R. H. M. J. Lemmens, Plant Resources of South-East Asia: Medicinal and Poisonous Plants 1, Prosea Foundation, Bogor, Indonesia, 1999.

[9] R. T. Dewi, Y. M. Iskandar, M. Hanafi et al., "Inhibitory effect of Koji Aspergillus terreus on $\alpha$-glucosidase activity and postprandial hyperglycemia," Pakistan Journal of Biological Sciences, vol. 10, no. 18, pp. 3131-3135, 2007.

[10] S. Sugiwati, S. Setiasi, and E. Afifah, "Antihyperglycemic activity of the mahkota dewa [Phaleria macrocarpa (scheff.) boerl.] leaf extracts as an alpha-glucosidase inhibitor," Makara Kesehatan, vol. 13, no. 2, pp. 74-78, 2009.

[11] A. Andrade-Cetto, J. Becerra-Jiménez, and R. CárdenasVázquez, "Alfa-glucosidase-inhibiting activity of some Mexican plants used in the treatment of type 2 diabetes," Journal of Ethnopharmacology, vol. 116, no. 1, pp. 27-32, 2008.

[12] D. S. Lee and S. H. Lee, "Genistein, a soy isoflavone, is a potent $\alpha$-glucosidase inhibitor," FEBS Letters, vol. 501, no. 1-3, pp. 84-86, 2001.

[13] K. B. Storey, Functional Metabolism: Regulation and Adaptation, Wiley-Interscience, Hoboken, NJ, USA, 2004. 

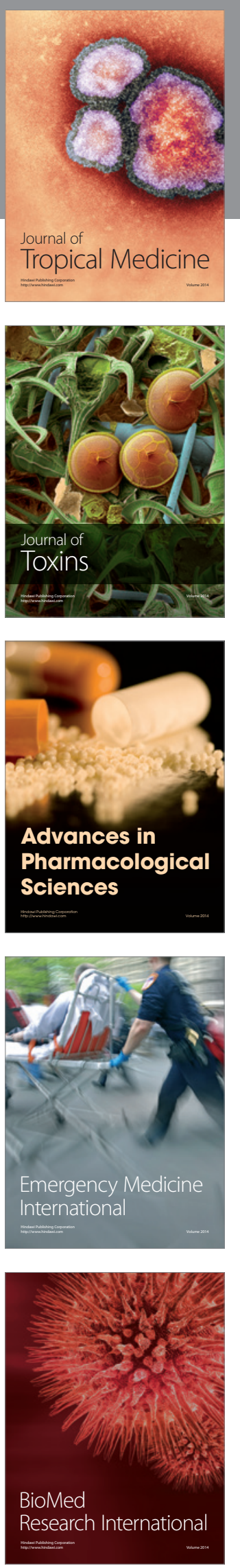
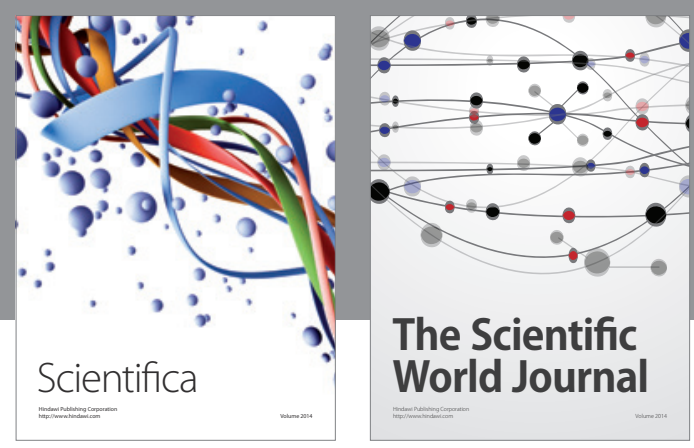

The Scientific World Journal
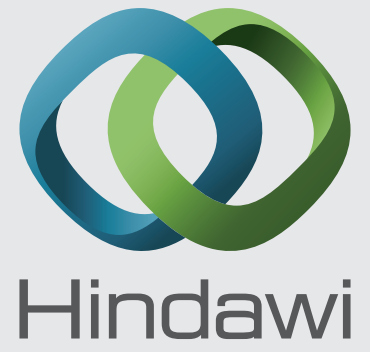

Submit your manuscripts at

http://www.hindawi.com
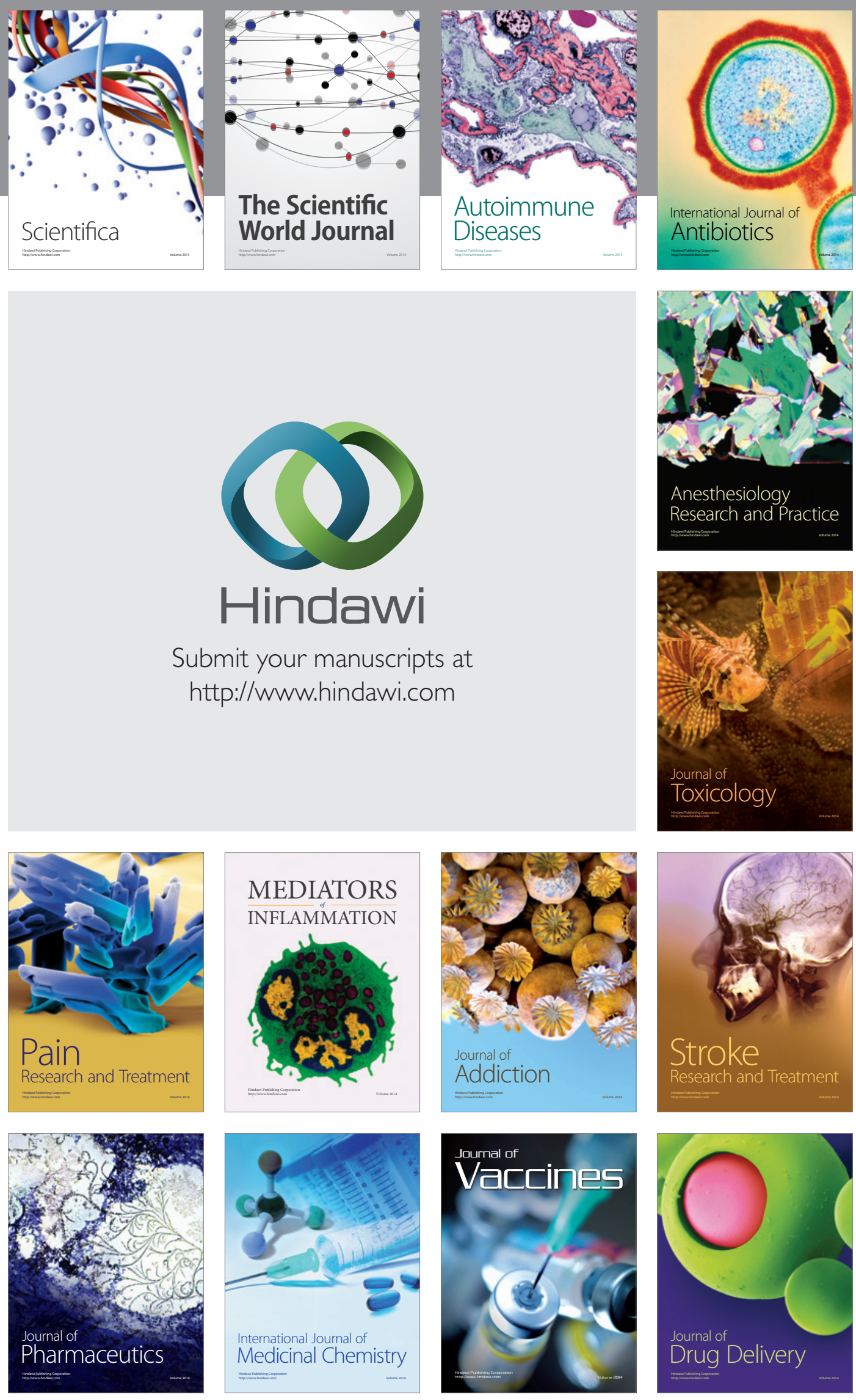